Warszawskie Studia Pastoralne UKSW

Rok XII 2017 Nr 1(34)

GRZEGORZ ŁĘCICKI

\author{
JAN PAWEŁ II - PAPIEŻ MEDIÓW \\ John Paul II: The Hero in the Age of Mass Media
}

Wybór papieża w czasach nowożytnych zawsze stanowił doniosłe wydarzenie dla Kościoła i świata. Warto przypomnieć, że oryginalnym tego świadectwem jest początek jednej z najważniejszych powieści w dziejach polskiej literatury, a mianowicie Lalki Bolesława Prusa ${ }^{1}$. Wraz z rozwojem kolejnych - obok prasy - środków społecznego przekazu, a więc filmu, radia i telewizji, każde współczesne konklawe stawało się wydarzeniem medialnym o coraz większym zasięgu, gdyż docierało do coraz większej zainteresowanych nim liczby odbiorców. Rozmaitość form przekazu medialnego - od słowa pisanego po komunikaty audialne oraz audiowizualne - również wpłynęła na globalne znaczenie wiadomości o wyborze papieża. Na zwiększone zainteresowanie mediów październikowym konklawe, obradującym w 1978 r. wpłynęło także to, że miało ono wybrać już drugiego papieża w tym samym roku.

Po śmierci Pawła VI, która nastąpiła 6 sierpnia 1978 r., jego następcą został wybrany 26 sierpnia 1978 r. patriarcha Wenecji, kardynał Albino Luciani. Jego podwójne imię: Jan Paweł I - pierwsze takie w historii papiestwa - wyraźnie symbolizowało wolę kontynuowania dzieła dwóch poprzedników, czyli papieży soborowych: Jana XXIII i Pawła VI. Niespodziewana śmierć Jana Pawła I w nocy z 28 na 29

1 Pierwsze zdanie powieści określa jej chronologię: „W początkach roku 1878, kiedy świat polityczny zajmował się (...) wyborem nowego papieża (...) warszawscy kupcy tudzież inteligencja pewnej okolicy Krakowskiego Przedmieścia (...) interesowała się przyszłością galanteryjnego sklepu pod firmą J. Mincel i S. Wokulski.” B. Prus, Lalka, t. I, Warszawa 2003, s. 3. 
września 1978 r. oraz jeden z najkrótszych pontyfikatów w dziejach Stolicy Apostolskiej stanowiły wielką sensację przyciągającą uwagę mediów i ich odbiorców. Dla dotychczasowego schematu medialnego, odnoszącego się do wyboru papieża, wynik kolejnego konklawe miał stanowić swoistą kulminację tego ciągu dramatycznych wydarzeń.

\section{Sensacja stulecia}

Dokonany w poniedziałek 16 października 1978 r. wybór metropolity krakowskiego, polskiego kardynała Karola Wojtyły na Stolicę Piotrową stał się największą sensacją XX wieku. Po raz pierwszy w historii papieżem został Słowianin. Od 455 lat na tronie Piotrowym miał zasiąść nie-Włoch. Biskupem Rzymu został wybrany hierarcha stosunkowo dość młody i to z kraju komunistycznego, pozostającego pod hegemonią Związku Sowieckiego. Wszystko, co dotyczyło osoby nowego papieża, było zaskakujące i odkrywcze. Natychmiast okazało się, że wynik konklawe nie stanowił punktu kulminacyjnego, ale początek wydarzeń wielkich i nieprzewidywalnych, będących dla mediów znakomitym materiałem do rozpowszechniania oraz komentowania. Pierwsze godziny i dni pontyfikatu pokazały, że będzie on sprawowany w sposób dotąd nieznany oraz wyjątkowy. Pierwsze publiczne wystąpienie Jana Pawła II zrywało z dotychczasową praktyką, ograniczającą się do udzielenia błogosławieństwa. Wbrew tradycji Jan Paweł II krótko przemówił do zgromadzonych na Placu Św. Piotra, a nawet wplótł pewien element humorystyczny, co wywołało owacyjną reakcję zebranych.

Dosłownie cały świat chciał jak najszybciej bliżej poznać biografię papieża-Polaka. Pierwszych syntetycznych wiadomości dostarczyło wydanie nadzwyczajne „L’Osservatore Romano”. Agencje informacyjne oraz redakcje wszystkich rodzajów mediów starały się zebrać i nagłaśniać jak najwięcej szczegółów z życia oraz dotychczasowej posługi nowego papieża. Rodzinne miasto Karola Wojtyły, Wadowice, 
a także jego biskupia stolica, Kraków, przeżyły istną inwazję dziennikarzy z całego świata ${ }^{2}$.

$Z$ relacji medialnych wyłaniał się niezwykły obraz osobowości i doświadczeń Jana Pawła II: urodzony i wychowany w patriotycznej rodzinie wojskowej w wolnej Polsce, naznaczony w dzieciństwie cierpieniem z powodu śmierci najpierw matki, potem brata, lekarza heroicznie wypełniającego swe powołanie, miłośnik literatury i sztuki aktorskiej, student najstarszej polskiej uczelni, czyli Uniwersytetu Jagiellońskiego, podczas okupacji osierocony przez ojca, konspirator i robotnik, który odkrył swe powołanie i w podziemiu studiował oraz przygotowywał się do kapłaństwa; kleryk znający koszmar wojny i bezmiar zbrodni, widzący zniewolenie Polski przez totalitaryzm hitlerowski, a następnie władzę komunistyczną podporządkowaną Związkowi Sowieckiemu, ksiądz studiujący w Rzymie, charyzmatyczny duszpasterz o bogatym doświadczeniu posługiwania w rozmaitych środowiskach, turysta, sportowiec, uczony i erudyta, poliglota, nauczyciel i wychowawca, poeta, aktor, dramaturg, publicysta, biskup, uczestnik II Soboru Watykańskiego oraz Synodu Biskupów, metropolita krakowski, świadek Wielkiego Jubileuszu Tysiąclecia Chrztu Polski i zmagania komunistycznego państwa z Kościołem, lojalny współpracownik prymasa Polski, kardynała Stefana Wyszyńskiego i tak jak on - wielki czciciel Matki Bożej. Imię nowego papieża jednoznacznie wskazywało na wolę kontynuowania dzieła poprzedników. Dziennikarzy zagranicznych, przybyłych do Polski w poszukiwaniu wiadomości o nowym papieżu, bardzo dziwił brak jego książek w księgarniach, co dobitnie świadczyło o specyficznej sytuacji Kościoła w PRL jako państwie totalitarnym³ ${ }^{3}$.

Na zapowiedzianą na niedzielę 22 października 1978 r. uroczystą Eucharystię mającą stanowić inaugurację pontyfikatu Jana Pawła II przybyły nie tylko liczne delegacje oficjalne oraz tysiące pielgrzymów

\footnotetext{
2 Por. G. Łęcicki, Jan Paweł II. Starałem się mówić za was. Opapieskich pielgrzymkach do zniewolonej Ojczyzny 1979, 1983, 1987, Warszawa 2008, s. 37-38.

3 Por. G. Łęcicki, Jan Paweł II. Miłośnik Krzyża i Zmartwychwstania, Warszawa 1998, s. 12-74.
} 
z całego świata, ale również wielka liczba dziennikarzy. Tak wielkiej grupy żurnalistów mających relacjonować i komentować to wydarzenie dotąd w Watykanie nie było. Podczas obrad II Soboru Watykańskiego wydano bowiem około tysiąca akredytacji ${ }^{4}$, natomiast na inaugurację pontyfikatu papieża-Polaka przybyło około dwóch tysięcy dziennikarzy. Kolejną sensacją pierwszych dni pontyfikatu Jana Pawła II stało się jego spotkanie z dziennikarzami, które odbyło się w przeddzień uroczystej inauguracji pontyfikatu, czyli w sobotę 21 października w sali Błogosławieństw. Sensację stanowił nie tylko fakt spotkania papieża z pracownikami mediów, ale przede wszystkim to, że owo spotkanie przerodziło się w oryginalną, spontaniczną konferencję prasową, podczas której papież odpowiadał na zadawane pytanie (nieraz niezbyt mądre) i - co było kolejnym wielkim zaskoczeniem - swobodnie posługiwał się kilkoma językami. Wielka komunikatywność, błyskawiczny refleks oraz żartobliwe, błyskotliwe wypowiedzi zjednywały papieżowi sympatię i przychylność ludzi mediów oraz przysparzały mu niezwykłej popularności ${ }^{5}$. Szczery uśmiech, poczucie humoru oraz niezwykłe walory intelektualne czyniły z papieża-Polaka gwiazdę mediów w najlepszym tego słowa znaczeniu i skupiały na nim uwagę świata.

Wolno przypuszczać, że Jan Paweł II, mający specyficzne doświadczenie medialne ${ }^{6}$, doskonale zdawał sobie sprawę z ogromnego znaczenia środków społecznego przekazu we współczesnym świecie, a szczególnie ich wpływu na sposób myślenia oraz interpretowania rzeczywistości; dlatego świadomie wybrał przekaz medialny jako jeden $\mathrm{z}$ istotnych sposobów obecności posługi papieskiej oraz misji Kościoła w kulturze masowej i popularnej. Na skalę dotąd przez

${ }^{4}$ Zob. 50 lat temu papież Jan XXIII otworzył obrady Soboru Watykańskiego II, http://dzieje.pl/aktualnosci/50-lat-temu-papiez-jan-xxiii-otworzyl-obrady-soboru-watykanskiego-ii (dostęp: 11.01.2016 r.).

5 Por. A. Podsiad, A. Szafrańska, Pierwsze dni pontyfikatu Jana Pawła II, Warszawa 1983, s. 17-23.

6 Por. G. Łęcicki, Media audiowizualne w nauczaniu Jana Pawła II, Warszawa 2013, s. 38-52. 
papieży nie praktykowaną Jan Paweł II zaczął się posługiwać mediami w dziele głoszenia Ewangelii.

\section{Wielki pontyfikat}

Pontyfikat Jana Pawła II był jednym z najdłuższych w dziejach Kościoła; trwał bowiem 26 lat 5 miesięcy i 17 dni; według tradycji przyjmuje się, że najdłużej przewodził Kościołowi św. Piotr (34 lata), zaś najdłuższym pontyfikatem jego następcy była posługa Piusa IX, trwająca od 1846 do 1878 r., a więc prawie 32 lata. W zależności od sposobu liczenia, a mianowicie łącznego lub rozdzielnego klasyfikowania pontyfikatu Benedykta IX, który trzy razy był wybierany na tron Piotrowy i trzy razy zeń usunięty (1032-1044, 1045, 1047-1048) oraz uwzględniania albo pomijania Stefana II (752 r.) zmarłego 4 dni po wyborze (zanim jeszcze został konsekrowany), przyjmuje się, że Jan Paweł II był 262. lub 265. papieżem7.

Bilans papieskiej posługi Jana Pawła II wygląda imponująco. Jan Paweł II ogłosił 14 encyklik, 15 adhortacji apostolskich, 13 konstytucji apostolskich, ponad 60 rozmaitych przesłań i listów, 27 orędzi na Światowy Dzień Pokoju, 13 orędzi na Światowy Dzień Chorego, 20 orędzi na Światowy Dzień Młodzieży oraz 26 orędzi na Światowy Dzień Środków Społecznego Przekazu'. Promulgował nowy Kodeks Prawa Kanonicznego (1983 r.) oraz ogłosił nowy Katechizm Kościoła Katolickiego (1992 r.).

Jan Paweł II, sam nazywający siebie Papieżem-Pielgrzymem ${ }^{9}$, odbył 104 pielgrzymki zagraniczne; odwiedził 129 krajów, a w nich 617 miejscowości. Podczas zagranicznych podróży apostolskich, których łączny czas trwania wyniósł 543 dni, Jan Paweł II wygłosił 2382

7 Por. K. Dopierała, Księga papieży, Poznań 1996, s. 11-12, 89, 134-136, 385-389.

8 Zob. S. Karczewski, Jan Paweł II. Encyklopedia pontyfikatu 1978-2005, Radom 2005, s. 548-560, J. Poniewierski, Pontyfikat 1978-2005, Kraków 2005, s. 463-466.

9 Zob. A. Jackowski, I. Sołjan, Wstęp, w: Leksykon pielgrzymek Jana Pawła II, red. A. Jackowski, I. Sołjan, Kraków 2005, s. 7. 
oficjalne przemówienia i homilie, a przemierzył 1162615 kilometrów, co obrazowo można porównać do 29 okrążeń Ziemi ${ }^{10}$.

Poza pielgrzymkami zagranicznymi Jan Paweł II odbył również 146 podróży apostolskich po Włoszech; odwiedził 259 miejscowości, wygłosił 906 oficjalnych przemówień i homilii. Pielgrzymowanie po Włoszech zajęło łącznie 278 dni. Oblicza się, że poza Watykanem Jan Paweł II spędził prawie 9 procent pontyfikatu. W diecezji rzymskiej odbył 748 wizyt duszpasterskich, w tym 301 wizytacji duszpasterskich ${ }^{11}$.

Papież-Polak pielgrzymował do Ojczyzny 9 razy, a mianowicie w 1979, 1983, 1987, 1991 (dwukrotnie: w czerwcu oraz w sierpniu z okazji Światowych Dni Młodzieży w Częstochowie), 1995, 1997, 1999 i 2002 r. Papieskie nauczanie, głoszone podczas pierwszej pielgrzymki, stanowiło istotny impuls późniejszych przemian politycznych, dokonujących się w Polsce pod wpływem „Solidarności” jako ruchu społecznego; podczas kolejnych dwóch pielgrzymek papież podtrzymywał nadzieję na ostateczne zwycięstwo nad komunizmem, a gdy ono faktycznie się dokonało, uczył odpowiedzialnego korzystania z odzyskanej wolności i suwerenności.

Jan Paweł II jako Najwyższy Kapłan Kościoła katolickiego udzielał wszystkich sakramentów: święcił diakonów, kapłanów i biskupów, chrzcił dzieci i dorosłych, udzielał Pierwszej Komunii św., bierzmował, błogosławił związki małżeńskie, spowiadał, namaszczał chorych.

Z inicjatywy papieża powstało w Watykanie w $1988 \mathrm{r}$. schronisko dla ubogich ${ }^{12}$. Jan Paweł II ufundował także w Watykanie w 1994 r. żeński klasztor kontemplacyjny ${ }^{13}$. Mianował rekordową liczbę kardynałów: 231, w tym 10 Polaków ${ }^{14}$.

\footnotetext{
10 Zob. S. Karczewski, Jan Paweł II. Encyklopedia pontyfikatu 1978-2005, dz. cyt., s. 305.

11 Por. tamże, s. 401, 305.

12 Zob. J. Poniewierski, Pontyfikat 1978-2005, Kraków 2005, s. 163.

13 Por. tamże, s. 252.

14 Zob. S. Karczewski, Jan Paweł II. Encyklopedia pontyfikatu 1978-2005, s. 508-519.
} 
Przewodniczył 6 zwyczajnym, 7 specjalnym i 1 nadzwyczajnemu Zgromadzeniu Ogólnemu Synodu Biskupów oraz 1 synodowi partykularnemu Kościoła lokalnego ${ }^{15}$. Ustanowił Papieską Radę ds. Rodziny (1981 r.), Papieską Radę Kultury (1982 r.), a także Papieską Akademię Nauk Społecznych oraz Papieską Akademię Obrony Życia (1994 r.) ${ }^{16}$. Dokonał reformy Kurii Rzymskiej (1988 r.) oraz zarządził nowy podział administracyjny Kościoła w Polsce (w 1992 i 2004 r.) ${ }^{17}$.

Jan Paweł II ustanowił (1992 r.) Światowy Dzień Chorego oraz zainicjował (1985 r.) Światowe Dni Młodzieży. W 1995 r. we Mszy św. w stolicy Filipin, Manili, podczas Światowych Dni Młodzieży, uczestniczyło ponad 4 miliony wiernych, co było pierwszym tak wielkim zgromadzeniem w historii ludzkości ${ }^{18}$. Przygotował Wielki Jubileusz Dwutysiąclecia Chrześcijaństwa i wprowadził Kościół w trzecie tysiąclecie; był więc papieżem przełomu stuleci, a zarazem tysiącleci.

Kanonizował oraz beatyfikował rekordową liczbę osób; ogłosił 482 nowych świętych, w tym 9 Polaków oraz 1338 nowych błogosławionych, w tym 155 Polaków. Najliczniejszą grupę wyniesionych na ołtarze stanowili męczennicy: 402 świętych i 1031 błogosławionych ${ }^{19}$.

Gorliwie angażował się w dialog międzyreligijny oraz ekume$n^{n i z m}{ }^{20}$. Jako pierwszy papież w historii „przekroczył progi anglikańskiej katedry w Canterbury"21, odwiedził zbór ewangelicko-luterański (w Rzymie w 1983 r. $^{22}$ ), synagogę (w Rzymie w $1986 \mathrm{r}^{23}$ ) oraz meczet

\footnotetext{
15 Por. tamże, s. 524.

16 Por. J. Poniewierski, Pontyfikat 1978-2005, dz. cyt., s. 62, 75, 253.

17 Por. tamże, s. 163, 219.

18 Zob. tamże, s. 116, 219, 262.

19 Zob. S. Karczewski, Jan Paweł II. Encyklopedia pontyfikatu 1978-2005, dz. cyt., s. $445,491$.

20 Por. E. Sakowicz, Dialog międzyreligijny, w: Jan Paweł II. Encyklopedia dialogu i ekumenizmu, red. E. Sakowicz, Radom 2006, s. 139-158; Z. J. Kijas, Ekumenizm, w: Jan Paweł II. Encyklopedia dialogu i ekumenizmu, dz. cyt., s. 172-198.

21 J. Poniewierski, Pontyfikat 1978-2005, dz. cyt., s. 68.

22 Por. P. Janowski, Protestantyzm, w: Jan Paweł II. Encyklopedia dialogu..., dz. cyt., s. 415.

${ }^{23}$ Por. W. Chrostowski, Judaizm, w: Jan Paweł II. Encyklopedia dialogu..., dz. cyt., s.299.
} 
(w Damaszku w 2001 r. $^{24}$ ), a także siedzibę Światowej Rady Kościołów w Genewie (1984 r.). Na papieskie zaproszenie do Asyżu (1986 r.) przybyli przedstawiciele innych wyznań i religii, by się wspólnie modlić o pokój.

Jan Paweł II przemawiał na forum znaczących organizacji międzynarodowych i politycznych: w ONZ (1979 r.), UNESCO (1980 r.), MOP (1982 r.), EWG (1985 r.) FAO (1992 r.), Międzynarodowym Trybunale Sprawiedliwości (1985 r.) oraz w Radzie Europy, Parlamencie Europejskim, Komisji i Trybunale Praw Człowieka (1988 r.), gdzie zdecydowanie poparł ideę zjednoczonej Europy ${ }^{25}$. W 1999 r. przemawiał w Sejmie RP; było to pierwsze w historii papiestwa wystąpienie Biskupa Rzymu w narodowym parlamencie ${ }^{26}$.

W sposób decydujący, poprzez nauczanie o godności i wolności człowieka, a także przekonanie o wewnętrznych sprzecznościach ustroju komunistycznego, przyczynił się do jego upadku w Europie Środkowo-Wschodniej. W tym kontekście należy przypomnieć, że Jan Paweł II nie został zaproszony ani do Rosji, ani do Chin. Po 1989 r. stały się natomiast możliwe pielgrzymki papieskie do krajów dawnego tzw. bloku wschodniego oraz niektórych dawnych republik sowieckich, które odzyskały niepodległość. Jan Paweł II odbył więc pielgrzymki do Czechosłowacji (1990 r.), na Węgry (1991 i 1996 r.), do Albanii (1993 r.), na Litwę, Łotwę i do Estonii (1993 r.), Chorwacji (1994, 1998 i 2003 r.), Czech (1995 i 1997 r.), na Słowację (1995 i 2003 r.), do Słowenii (1996 i 1999 r.), Bośni i Hercegowiny (1997 i 2003 r.), na Kubę (1998 r.), do Rumunii (1999 r.), Gruzji (1999 r.), na Ukrainę (2001 r.), do Kazachstanu i Armenii (2001 r.), Azerbejdżanu i Bułgarii $(2002 \mathrm{r} .)^{27}$.

\footnotetext{
24 Por. E. Sakowicz, Islam, w: Jan Paweł II. Encyklopedia dialogu..., dz. cyt., s. 256.

25 Zob. J. Poniewierski, Pontyfikat 1978-2005, dz. cyt., s. 31-32, 46, 70, 160, 235,

26 Por. tamże, s. 317.

27 Zob. Leksykon pielgrzymek Jana Pawła II, dz. cyt., s. 234-236, 309-310, 312, 323-324, 345-346, 376, 389-391, 393-395, 397-400, 402-406, 411, 454-455, 460-461, 515-516, 520-524, 526-528, 539-541, 543-545.
} 
Jan Paweł II dwukrotnie stał się celem zamachu: 13 maja 1981 r. na Pl. św. Piotra w Rzymie oraz 12 maja 1982 r. w Fatimie ${ }^{28}$.

Jako papież nadal dbał o kondycję fizyczną, uprawiał sport: pływał, jeździł na nartach, odbywał piesze wycieczki w góry. „Wycieczki poza Rzym, zwłaszcza w góry, były dla niego (...) okazją do rozmyślań, a przede wszystkim do modlitwy. Tamta sceneria harmonizowała z jego duchowością. W górach kontemplował dzieła Pana, powierzał się ich Stwórcy"29.

Ostatnia choroba papieża, umieranie, odchodzenie do domu Ojca odbyło się na oczach świata. „Jan Paweł II przeszedł «z życia do życia» w dzień maryjny - pierwszą sobotę miesiąca - i w liturgiczne święto Miłosierdzia Bożego. To przejście do wieczności na oczach całej rodziny ludzkiej było ostatnią katechezą Jana Pawła II, w której mówił, że chwile cierpienia i śmierci należy przeżywać w świetle wiary, z miłością i nadzieją chrześcijańską, z całkowitym zdaniem się na wolę Bożą, służąc do końca Kościołowi i zbawieniu ludzi. Milcząca katecheza Ojca Świętego była punktem szczytowym jego Magisterium. Usłyszał ją i zapamiętał cały Kościół i świat"30.

Spośród rozmaitych prób interpretowania fenomenu osobowości i pontyfikatu Jana Pawła II na szczególna uwagę zasługuje opinia jego długoletniego najbliższego współpracownika, kard. Stanisława Dziwisza: „Karol Wojtyła mówił o Bogu językiem dzisiejszego człowieka. Wczuwał się w jego sposób myślenia, a jednocześnie pochylał się nad nim, nad jego problemami. Także nad jego brakiem konsekwencji i niewiernością (...) papież Wojtyła położył fundamenty pod nową duchowość (...) zdolną wyrazić lepiej wewnętrzne bogactwo świeckiego chrześcijanina i jednocześnie pomagającą mu przenieść to bogactwo w sferę doczesną, w obszar jego zaangażowania społecznego"31.

\footnotetext{
28 Por. J. Poniewierski, Pontyfikat 1978-2005, dz. cyt., s. 51, 67.

29 S. Dziwisz, Świadectwo $w$ rozmowie $z$ Gian Franco Svidercoschim, Warszawa 2007, s. 78 .

30 S. Dziwisz, C. Drążek, Cierpienie w życiu i nauczaniu Jana Pawła II, w: Pozwólcie mi odejść. Siła w słabości Jana Pawła II, Częstochowa 2006, s. 53.

31 S. Dziwisz, U boku Świętego. Rozmowa z Gian Franco Svidercoschim, Kraków 2013, s. 14, 154.
} 
Jan Paweł II został ogłoszony błogosławionym podczas uroczystości beatyfikacyjnej celebrowanej w Watykanie na Placu św. Piotra 1 maja 2011 r. przez papieża Benedykta XVI, natomiast jego kanonizacji dokonał tamże papież Franciszek w niedzielę Miłosierdzia Bożego 27 kwietnia 2014 r. Liturgiczne wspomnienie św. Jana Pawła II obchodzone jest 22 października, przypominającym datę uroczystej inauguracji jego pontyfikatu.

\section{Bohater i odbiorca mediów}

Każde z wyliczonych wyżej wydarzeń i faktów znajdowało odbicie $\mathrm{w}$ światowych mediach. Wolno zaryzykować twierdzenie, że w pewnym momencie niecodzienność i dynamika sposobu sprawowania papieskiej posługi przez Jana Pawła II niejako spowszedniała, gdyż zarówno media, jak i ich odbiorcy jakby się przyzwyczaili do niezwykłych informacji dotyczących papieża-Polaka; mówiąc paradoksalnie: niecodzienność stała się codziennością. Intensywność jego pontyfikatu, nagromadzenie wyjątkowych faktów i wydarzeń stały się, w co obecnie pewnie trudno uwierzyć, zbyt szybkie nawet dla samych mediów, a zarazem utrudniały percepcję i zapamiętanie przez odbiorców. Należy również zauważyć, że postrzeganie osoby oraz posługiwania Jana Pawła II odbywało się głównie poprzez tzw. media tradycyjne, czyli prasę, radio, telewizję, później wprawdzie również przez Internet, ale - co warto podkreślić - było niemal nieobecne w rozwijających się dziś dynamicznie mediach społecznościowych; Wikipedia pojawiła się w Sieci w styczniu 2001 r., Facebook powstał w lutym 2004 r., YouTube - w lutym 2005 r., a Twitter - w marcu 2006 r. $^{32}$ Dopiero więc następcy Jana Pawła II: Benedykt XVI (2005-2013) oraz Franciszek mogli się posługiwać tymi najnowszymi kanałami komunikacji, docierającymi przede wszystkim do nowego pokolenia młodych użytkowników.

Jan Paweł II komunikował się ze światem, wykorzystując rozmaite znane i dostępne wtedy sposoby rozpowszechniania myśli, opinii, informacji. Wśród nich był tak tradycyjny gatunek, jaki stanowi

32 Zob. P. Levinson, Nowe nowe media, Kraków 2010, s. 98, 137, 190, 208. 
wywiad dziennikarski. Mające formę książek publicystyczne relacje ze spotkań oraz rozmów z papieżem stawały się światowymi bestsellerami $^{33}$, podobnie jak i autobiograficzne wspomnienia Jana Pawła $\mathrm{II}^{34}$. Ujawniały oraz przybliżały czytelnikom nie tylko szczegóły życiorysu papieża-Polaka, ale przede wszystkim ukazywały jego duchowość, ideały oraz źródła formacji intelektualnej, fundamenty nauczania, doświadczenie Boga, obraz człowieka, wizję współczesnego świata i misji Kościoła. Wydarzeniem bez precedensu stało się udzielenie przez papieża wywiadu dla dziennika „La Stampa” na temat aktualnych kwestii społecznych i politycznych ${ }^{35}$.

Oprócz wywiadów mających tradycyjną formę słowa drukowanego, Jan Paweł II udzielił także wywiadu telewizyjnego podczas pielgrzymki do Norwegii w 1989 r. ${ }^{36}$ Poprzez radio i telewizję były rozpowszechniane nagrane wcześniej orędzia papieża m.in. do mieszkańców kraju, do którego Jan Paweł II miał wkrótce przybyć, jak np. do Francji w 1986 r. $^{37}$, lub który obchodził rocznicę jego pielgrzymki; tak było w przypadku Wenezueli w $1986 \mathrm{r}^{38}$. „Przebywając na Filipinach, Jan Paweł II - za pośrednictwem katolickiego Radia Veritas (którego program dociera do 2 mld słuchaczy w 21 krajach Azji) wygłosił orędzie do chińskich katolików" ${ }^{39}$. Podczas pielgrzymki do

\footnotetext{
33 Zob. A. Frossard, „Nie lękajcie się!” Rozmowy z Janem Pawłem II, Watykan 1982; Przekroczyć próg nadziei. Jan Paweł II odpowiada na pytania Vittoria Messoriego, Lublin 1994; Jan Paweł II, Pamięć i tożsamość. Rozmowy na przełomie tysiącleci, Kraków 2005.

${ }^{34}$ Zob. Jan Paweł II, Dar i Tajemnica. W pięćdziesiąta rocznicę moich święceń kapłańskich, Kraków 1996; Jan Paweł II, Wstańcie, chodźmy!, Kraków 2004.

${ }_{35}$ Zob. Ku jakiej zmierzamy Europie? Wywiad udzielony Jasiowi Gawrońskiemu dnia 24 października 1993 r. w Rzymie, w: Jan Paweł II, Nauczanie społeczne Kościoła integralną częścią Jego misji. Wywiady, Rzym 1996; J. Poniewierski, dz. cyt., s. 251-252.

36 Zob. Rekordy pontyfikatu papieża Jana Pawła II. O pontyfikacie Jana Pawła II, www.antoni.agmk.net/index.php?go=swieci_1/JP_II/rekordy (dostęp: 01.03.2016 r.).

37 Zob. S. Karczewski, Jan Paweł II. Encyklopedia pontyfikatu 1978-2005, dz. cyt., s. 134 .

38 Por. tamże, s. 129.

39 J. Poniewierski, Pontyfikat 1978-2005, dz. cyt., s. 262.
} 
Kanady w 1984 r. z Vancouveru wyemitowano przemówienie papieża do Indian i Eskimosów oczekujących na spotkanie z Janem Pawłem II w Fort Simson ${ }^{40}$; z powodu złych warunków atmosferycznych papież nie mógł tam wtedy przybyć; spotkanie z rdzennymi mieszkańcami Kanady odbyło się w Fort Simpson podczas kolejnej pielgrzymki papieskiej w 1987 r. ${ }^{41}$ Podczas pielgrzymki do Chile w 1987 r. poprzez telewizję nadano papieskie orędzia do mieszkańców pustynnych terenów Norte Grande oraz Wyspy Wielkanocnej ${ }^{42}$. W czasie pielgrzymki do Boliwii w 1988 r. stołeczna telewizja w La Paz nadała z okazji Dnia Dziennikarza papieskie orędzie do ludzi mediów ${ }^{43}$.

Za swoistą i oryginalną formę komunikacji należy także uznać publikowanie papieskiej poezji. Ten niezwykły, jak na papieża, sposób wyrażania siebie był świadectwem zarówno talentu artystycznego, potrzeby tworzenia, wrażliwości literackiej, jak i przekonania o tym, że poezja jako najpiękniejsza forma werbalizacji może stanowić istotny czynnik ewangelizacji oraz opisu emocji i przedstawiania tego, co niewyrażalne, co niejako z natury jest niedostępne suchej, prozaicznej narracji faktograficznej. Należy zauważyć, że zainteresowanie poezją Karola Wojtyły - Jana Pawła II i przetłumaczenie jego wybranych utworów literackich na ponad 30 języków stanowiło wyjątkową formę promocji polskiej kultury ${ }^{44}$. Papieska poezja stała się także inspiracją dla innych twórców i muzyków, nadających wierszom Karola Wojtyły kształt refleksyjnych pieśni ${ }^{45}$. Warto jednak zaakcentować, że dla papieża poezja była przede wszystkim wyrazem aktu wiary, a nie popisem literackim. Podobnie było w przypadku rozpowszechniania

\footnotetext{
40 Zob. S. Karczewski, Jan Paweł II. Encyklopedia pontyfikatu 1978-2005, dz. cyt., s. 328.

41 Zob. Leksykon pielgrzymek Jana Pawła II, dz. cyt., s. 224, 226-227.

42 Por. tamże, s. 166; S. Karczewski, Jan Paweł II. Encyklopedia pontyfikatu 1978-2005, dz. cyt., s. 342 .

43 Por. tamże, s. 347.

44 Por. G. Łęcicki, Nachylenie Boga. O młodzieńczej poezji Karola Wojtyły, Warszawa 2006, s. 9-10.

45 Zob. np. Pieśń o Bogu ukrytym. Wiersze Karola Wojtyły śpiewa Marcin Styczeń, CD, Warszawa-Olkusz 2006.
} 
nagrań na płytach CD z głosem papieża, śpiewającego Modlitwę Pańską. Obecnie na kanale YouTube można usłyszeć zarówno to nagranie $^{46}$, jak i oglądać papieża, spontanicznie śpiewającego Góralu czy ci nie żal z chórem japońskim ${ }^{47}$. Takie niekonwencjonalne sposoby komunikacji przyczyniały się oczywiście do wzrostu popularności papieża, przybliżały jego osobę i posługę oraz czyniły ją bardziej zrozumiałą. W tym dziele niezastąpionym narzędziem okazywały się oczywiście środki społecznego przekazu. Wyjątkowym znakiem afirmacji świata mediów było powierzenie przez papieża w 2002 r. prowadzenia rozważań Drogi krzyżowej czternastu dziennikarzom akredytowanym w Watykanie ${ }^{48}$.

Spotkania papieża $\mathrm{z}$ dziennikarzami, relacjonującymi jego zagraniczne pielgrzymki, stały się swoistym, stałym obyczajem. W papieskim samolocie (którym bywał potężny Boeing 747 albo McDonnell Douglas MD-11, a na krótszych dystansach Airbus A-321) jeden $\mathrm{z}$ przedziałów był nieodmiennie przeznaczony dla dziennikarzy relacjonujących zagraniczne papieskie podróże apostolskie. Jan Paweł II przychodził do owego przedziału dla ludzi mediów i wtedy odbywały się bezpośrednie rozmowy oraz spontaniczne - dosłownie podniebne - konferencje prasowe ${ }^{49}$.

Jan Paweł II udzielał licznych audiencji reprezentantom rozmaitych organizacji dziennikarskich oraz wielokrotnie spotykał się z przedstawicielami najprzeróżniejszych środowisk oraz instytucji medialnych. Inną formę kontaktu Jana Pawła II z redakcjami oraz ludźmi mediów stanowiły kierowane do nich papieskie listy dotyczące rozmaitych kwestii ogólnych i szczegółowych. Okazje do spotkań stanowiły zarówno pielgrzymki zagraniczne, jak i jubileusze redakcji, np. 120-lecie „L’Osservatore Romano”, 100-lecie „La Croix”, 50-lecie

\footnotetext{
46 Zob. Jan Paweł II - Papież śpiewa, www.youtube.com/watch?v=9F5GYItlhYE (dostęp: 01.03.2016 r.).

47 Zob. Papież Jan Paweł II śpiewa „Góralu czy ci nie żal” z Japończykami, www. youtube.com/watch?v=KajTXhPUqCM (dostęp: 01.03.2016 r.).

48 Por. B. Lecomte, Pasterz, Kraków 2006, s. 659.

49 Por. G. Łęcicki, Jan Paweł II. Miłośnik Krzyża..., dz. cyt., s. 129, 131.
} 
„Passauer Bistumsblatt”, 40-lecie „Tygodnika Powszechnego”, 70-lecie „Niedzieli”, 75-lecie „Gościa Niedzielnego”. Antologia papieskich wypowiedzi skierowanych do ludzi mediów, dziennikarzy prasowych, radiowych i telewizyjnych zawiera 113 tekstów ${ }^{50}$; do tego należy jeszcze doliczyć blisko 50 okazjonalnych wypowiedzi o mediach, kierowanych do różnych grup oraz instytucji ${ }^{51}$. Osobny zbiór stanowi 19 przemówień wygłoszonych przez Jana Pawła II do członków i konsultantów Papieskiej Rady ds. Środków Społecznego Przekazu ${ }^{52}$. Tak liczne i bogate w treść papieskie wypowiedzi oraz dokumenty poświęcone problematyce środków społecznego przekazu w pełni uprawniają do sformułowania tezy o oryginalnej doktrynie medialnej Jana Pawła II, która w decydujący sposób przyczyniła się do swoistej ewolucji i przemiany aktualnej relacji między Kościołem a mediami.

Należy jeszcze raz zauważyć, że papież-Polak nie bał się otwartości wobec świata i ludzi mediów, choć niosła ona z sobą także pewien element ryzyka; zdarzało się bowiem, że dziennikarze niezbyt taktownie prezentowali wobec Jana Pawła II rozmaite poglądy. Tak się zdarzyło w 1988 r. gdy „pewien dziennikarz przyznający się do żydowskiego pochodzenia oskarżył Ojca Świętego o... banalizacje Holocaustu (...). Z twarzy Papieża można było wyczytać, że pytanie boleśnie go dotknęło. Rozłożył ręce. «Zdumiewa mnie - nie potrafię powiedzieć nic innego - zdumiewa mnie pańskie pytanie»"53.

Spośród licznych spotkań papieża $\mathrm{z}$ dziennikarzami warto przypomnieć jako charakterystyczny przykład audiencję udzieloną 19 kwietnia 1986 r. żurnalistom ze Związku Radzieckiego ${ }^{54}$. Należy także pamiętać, że Jan Paweł II nie tylko spotykał się z ludźmi mediów w Watykanie, ale także bywał w ich miejscach pracy: 17 stycznia 1988 r. papież przybył do rzymskiej siedziby Stowarzyszenia Prasy

\footnotetext{
50 Zob. Media i dziennikarstwo w nauczaniu Jana Pawła II, red. A. Lewek, Warszawa 2008, s. 7-12.

51 Zob. tamże, s. 12-14.

52 Zob. tamże, s. 6-7.

53 J. Poniewierski, Pontyfikat 1978-2005, dz. cyt., s. 176.

54 Por. S. Karczewski, Jan Paweł II. Encyklopedia pontyfikatu 1978-2005, dz. cyt., s. 131.
} 
Zagranicznej ${ }^{55}$. Zagraniczne podróże apostolskie stanowiły kolejną okazję do wizyt w instytucjach medialnych; podczas pielgrzymki na Daleki Wschód w 1981 r. i pobytu w stolicy Filipin, Manili, papież przybył do siedziby Radia Veritas, by wygłosić orędzie do ludów Azji ${ }^{56}$.

Przypomniane wyżej przykłady w pełni potwierdzają słuszność opinii o tym, że Jan Paweł II jako pierwszy papież w historii świadomie i aktywnie tworzył wydarzenia medialne oraz kierował uwage środków społecznego przekazu na istotne problemy ludzkości ${ }^{57}$. Był w najszlachetniejszym tego słowa znaczeniu kreatorem przekazów medialnych; dzięki jego niezwykłej, medialnej osobowości transmisje telewizyjne stanowiły nową jakość przekazu harmonijnie łączącego dynamikę emisji z głębią duchową. Dzięki wykorzystaniu najnowszych, satelitarnych technik telewizyjnych Jan Paweł II mógł się modlić z młodzieżą akademicką uniwersyteckich miast europejskich oraz uczestniczyć w telemoście z Łagiewnikami w dniu kanonizacji św. Faustyny ${ }^{58}$.

Należy jeszcze przypomnieć, że Jan Paweł II bardzo dbał o dobre relacje z dziennikarzami; nazwał ich nawet przyjaciółmi, podkreślał znaczenie szacunku i wzajemnego zaufania, akcentował zbieżność dróg Kościoła i mediów w dziedzinie przekazu, apelował o wykorzystywanie środków społecznego przekazu zgodnie $\mathrm{z}$ ich fundamentalnym powołaniem do szerzenie prawdy, wspierania rozwoju oraz budowania dobra ${ }^{59}$. Jan Paweł II był więc nie tylko gwiazdą, bohaterem mediów, ale nie jako celebryta, lecz jako autorytet, sumienie świata ${ }^{60}$, również świata mediów.

\footnotetext{
55 Por. tamże, s. 146.

56 Por. tamże, s. 315.

57 Por.. A. Baczyński, Jan Paweł II - blask osoby w telewizji, w: A. Baczyński, M. Drożdż, Nie lękajcie się. Jan Paweł II i media, Kraków 2011, s. 117.

58 Por. tamże, s. 116.

59 Zob. Jan Paweł II, Misja dziennikarza wymaga kompetencji zawodowej i odpowiedzialności moralnej, w: Media i dziennikarstwo w nauczaniu Jana Pawła II, dz. cyt., s. 245, 248, 250.

60 Por. A. Riccardi, Jan Paweł II. Biografia, Częstochowa 2014, s. 473-476.
} 
Papież Jan Paweł II był nie tylko bohaterem mediów, ale również ich odbiorcą: „chciał być zawsze poinformowany o wszystkim. Czytał przegląd prasy i „L'Osservatore Romano”, a wieczorem oglądał telewizję (...). Śledził pierwszą część wiadomości” ${ }^{61}$, a także komunikaty dotyczące sportu. Szczególne znaczenie miały dla niego informacje o dramatycznych wydarzeniach w Polsce: o wprowadzeniu stanu wojennego (1981 r.), porwaniu i męczeńskiej śmierci ks. Jerzego Popiełuszki (1984 r.). „Oglądał czasem wybrane programy, filmy dokumentalne oraz fabularne nagrane wcześniej na magnetowidzie. W okresie Bożego Narodzenia Papieska Komisja ds. Środków Społecznego Przekazu przygotowywała dla papieża i najbliższych współpracowników specjalną projekcję w watykańskiej sali kinowej; wyświetlano wtedy starannie dobrane filmy uznane za wybitne dzieła kinematografii" ${ }^{62}$. Papież dostrzegał znaczącą rolę kina we współczesnej kulturze, lubił oglądać filmy ukazujące zmagania z problemami egzystencjalnymi, biografie świadków wiary i ludzi o bogatej duchowości. Co ciekawe, filmy stanowiły dla niego również źródło inspiracji ${ }^{63}$. Wydarzeniem bez precedensu w historii papiestwa było to, że w Watykanie 30 sierpnia 2001 r. w obecności Jana Pawła II i publiczności odbyła się światowa prapremiera filmu Quo vadis w reżyserii J. Kawalerowicza; wcześniej papież zobaczył obraz Teresy Kotlarczyk Prymas - trzy lata z tysiąca; zaś później, w 2004 r. podczas prywatnego pokazu, obejrzał Pasję M. Gibsona ${ }^{64}$.

Nie wolno zapominać również o tym, że Jan Paweł II stał się także bohaterem kilku mniej lub bardziej udanych filmów fabularnych oraz wielu obrazów dokumentalnych ${ }^{65}$. Jako ciekawostkę warto przypomnieć, że jedno ze spotkań papieża z młodzieżą podczas pielgrzymki

\footnotetext{
61 S. Dziwisz, Świadectwo..., dz. cyt., s. 84.

62 G. Łęcicki, Media audiowizualne w nauczaniu Jana Pawła II, Warszawa 2012, s. 51 .

${ }^{63}$ Zob. S. Dziwisz, Świadectwo..., dz. cyt., s. 85.

${ }^{64}$ Zob. J. Poniewierski, Pontyfikat 1978-2005, dz. cyt., s. 352, 394.

65 Por. A. Garbicz, M. Lis, Filmowe portrety pontyfikatu. Jan Paweł II w 100 odsłonach, Katowice 2007, s. 9-137; G. Łęcicki, Pierwsze polskie wizerunki filmowe Jana Pawła II, „Studia Theologica Varsaviensia” 2014, nr 1, s. 82-97.
} 
do Stanów Zjednoczonych w 1987 r. odbyło się w amfiteatrze wytwórni filmowej Universal w Hollywood; w Los Angeles, w hotelu Universal Studios papież spotkał się następnie z magnatami mediów i przemysłu rozrywkowego, a więc prasy, telewizji oraz kina ${ }^{66}$.

\section{Ewangelizator i twórca mediów}

Jana Pawła II słusznie nazywa się papieżem mediów nie tylko dlatego, że był ich bohaterem i umiał je świetnie wykorzystywać w dziele głoszenia Ewangelii oraz nauki Kościoła, ale także dlatego, iż zaakcentował konieczność i potrzebę ewangelizowania również świata środków społecznego przekazu. Najwyraźniej i najmocniej zabrzmiało to w encyklice Redemptoris missio, w której zdecydowanie apelował o podjęcie misji ewangelizacyjnej wobec mediów, stanowiących pierwszy areopag współczesnego świata ${ }^{67}$. Podobnie wypowiedział się również w kontekście określenia zadań i misji nowej ewangelizacji: „Musimy nie tylko posługiwać się środkami społecznego przekazu, aby mówić światu o Chrystusie, ale także głosić Ewangelię światu środków przekazu" ${ }^{68}$. W przemówieniach głoszonych do dziennikarzy, twórców i pracowników mediów papież podkreślał konieczność przestrzegania fundamentalnych zasad oraz ideałów etycznych, by przekaz medialny miał charakter pozytywny ${ }^{69}$, a także jasno i zdecydowanie piętnował występujące w mediach zjawiska negatywne ${ }^{70}$, uwłaczające godności człowieka i stanowiące zaprzeczenie ideałów prawdy, dobra i piękna poprzez lansowanie fałszywych wizji życia ${ }^{71}$.

\footnotetext{
66 Por. Leksykon pielgrzymek Jana Pawła II, dz. cyt., s. 270.

${ }^{67}$ Por. Jan Paweł II, Redemptoris missio. Encyklika o stałej aktualności posłania misyjnego, nr 37c, w: Encykliki Ojca Świętego Jana Pawła II, Kraków 2009, s. 554-555.

68 Jan Paweł II, Dobra Nowina w świecie mediów, w: Media i dziennikarstwo w nauczaniu Jana Pawła II, dz. cyt., s. 225.

69 Por. Jan Paweł II, Misja dziennikarza..., dz. cyt., s. 248.

70 Por. Jan Paweł II, Wskazania Kościoła w 100-lecie kinematografii, w: Media i dziennikarstwo w nauczaniu Jana Pawła II, dz. cyt., s. 212.

71 Por. Jan Paweł II, Telewizja w rodzinie: kryteria właściwego wyboru programów, w: Orędzia papieskie na Światowe Dni Komunikacji Społecznej 1967-2002, red. M. Lis, Częstochowa 2002, s. 193.
} 
Dziennikarzom katolickim przypominał o religijnym wymiarze ich powołania zawodowego ${ }^{72}$.

Papież-Polak był nie tylko ewangelizatorem mediów, ale zgodnie z wyrażanym przez siebie postulatem tworzenia katolickich środków społecznego przekazu stał się także twórcą nowych instytucji medialnych Stolicy Apostolskiej. W czasie pontyfikatu Jana Pawła II w 1983 r. powstał bowiem Watykański Ośrodek Telewizyjny ${ }^{73}$, zaś w 1995 r. została uruchomiona - prowadzona przez amerykańską franciszkankę, s. Judith Zoebelein - strona internetowa Stolicy Apostolskiej; serwery zapewniające obecność Watykanu w Sieci noszą imiona trzech archaniołów (Rafał, Michał, Gabriel) ${ }^{74}$; w marcu 2003 r. na stronie internetowej Stolicy Apostolskiej zanotowano ponad 3,5 miliona odwiedzin, czyli ok. 116 tysięcy wizyt dziennie ${ }^{75}$. W $2001 \mathrm{r}$. papież przesłał Kościołowi posynodalną adhortację apostolską Ecclesia in Oceania posługując się pocztą elektroniczną ${ }^{76}$.

O wyjątkowej otwartości papieża-Polaka na świat mediów i realizacji nowej polityki informacyjnej znanego z dyskrecji i powściągliwości Watykanu świadczyło również to, że rzecznikiem prasowym Stolicy Apostolskiej, a dokładniej dyrektorem watykańskiego Biura Prasowego został w 1984 r. świecki dziennikarz hiszpański, lekarz, doktor psychiatrii, Joaquin Navarro-Valls ${ }^{77}$. Jedną z cech charakterystycznych prowadzonej przez niego polityki informacyjnej było nieutajnianie informacji dotyczących stanu zdrowia Jana Pawła II; media były więc informowane o kolejnych jego chorobach i operacjach: po zamachu (1981 r.), nowotworu niezłośliwego (1992 r.), barku (1993 r.), nogi (1994 r.), wyrostka robaczkowego (1996 r.) grypie

\footnotetext{
72 Por. Jan Paweł II, Dziennikarstwo jak kapłaństwo jest powołaniem, w: Media i dziennikarstwo w nauczaniu Jana Pawła II, dz. cyt., s. 243.

73 Zob. S. Karczewski, Jan Paweł II. Encyklopedia pontyfikatu 1978-2005, dz. cyt., s. 109.

74 Por. B. Lecomte, Pasterz, dz. cyt., s. 658.

75 Zob. R. Podpora, Watykan i internet, www.e-mentor.edu.pl/artykul/index/ numer/18/id/391 (dostęp: 13.03.2016 r.).

76 Zob. J. Poniewierski, Pontyfikat 1978-2005, dz. cyt., s. 358-359.

77 Por. A. Riccardi, Jan Paweł II. Biografia, dz. cyt., s. 438-439.
} 
$(2005 \text { r. })^{78}$. Nieukrywany i przekazywany poprzez media obraz cierpiącego i odchodzącego papieża przyczynił się do przywrócenia godności umierania. Kierowane przez J. Navarro-Vallsa Biuro Prasowe Stolicy Apostolskiej w 1991 r. rozpoczęło publikowanie codziennych biuletynów informacyjnych przeznaczonych dla dziennikarzy, redakcji oraz instytucji medialnych ${ }^{79}$.

\section{Realizator edukacji medialnej}

Kontynuując i rozwijając nauczanie Pawła VI o mediach, Jan Paweł II często zwracał się do społeczności wiernych oraz opinii publicznej, apelując do odbiorców mediów, a szczególnie rodziców, by uczyli dzieci i młodzież „właściwego i odpowiedzialnego korzystania ze środków przekazu"80. Był więc dosłownie nauczycielem edukacji medialnej, której potrzebę stale dostrzegał. Wzywał Kościół do realizacji edukacji medialnej, rozumianej jako formowanie świadomych, krytycznych odbiorców środków społecznego przekazu, którzy będą potrafili dokonywać selektywnego wyboru przekazów medialnych i oceny moralnej zawartych w nich treści ${ }^{81}$. Papieski postulat nauczania o mediach nie znalazł, jak się wydaje, zbyt szerokiego posłuchu i nie spotkał się z powszechnym pozytywnym odzewem. Na poziomie nauczania uniwersyteckiego uczelnie katolickie realizują studia dziennikarskie, a w niektórych seminariach duchownych wykłada się sporadycznie problematykę komunikacji medialnej. Edukację medialną - poza nielicznymi wyjątkami - zaniedbują jednak katolickie licea, gimnazja i szkoły podstawowe. Parafie oraz inne instytucje kościelne wprawdzie coraz częściej i chętniej posługują się mediami, natomiast zdecydowanie rzadziej podejmują inicjatywy

\footnotetext{
78 Zob. J. Poniewierski, Pontyfikat 1978-2005, dz. cyt., s. 92, 94, 210, 275, 283, 405, 407, 408, 412-413.

79 Por. G. Weigel, Świadek nadziei. Biografia papieża Jana Pawła II, Kraków 2000, s. 622.

80 Jan Paweł II, Rola kaset magnetofonowych i magnetowidowych $w$ kształtowaniu kultury i sumienia, w: Orędzia papieskie..., dz. cyt., s. 190.

81 Zob. Jan Paweł II, Komunikacja społeczna pomostem pomiędzy wiarq a kultura, w: Orędzia papieskie..., dz. cyt., s. 123.
} 
formacyjne mające profil edukacji medialnej. W programach katechetycznych problematyka medialna najczęściej traktowana bywa marginalnie i jest redukowana wyłącznie do posługiwania się środkami audiowizualnymi jako narzędziami mającymi uatrakcyjnić przekaz werbalny ${ }^{82}$.

Papież Jan Paweł II doskonale rozpoznawał siłę i moc oddziaływania mediów na odbiorców, a przede wszystkim potęgę sugestywnych audiowizualnych przekazów medialnych, filmów i seriali, wpływających na przemianę obyczajów, mentalności, sposób zachowania, utratę poczucia grzechu. Wobec liberalizacji tradycyjnych norm i wartości oraz kwestionowania fundamentalnych zasad etyki katolickiej, papież niejednokrotnie przypominał twórcom kina i pracownikom telewizji o konieczności wspomagania procesu wychowania poprzez afirmację małżeństwa i rodziny jako wspólnoty życia, solidarności oraz miłości ${ }^{83}$. Jan Paweł II zwracał więc uwagę na to, że przekazy medialne wpływają na proces kształtowania sumienia i moralnej wrażliwości, tworzą obraz świata i człowieka, lansują autorytety, ale mogą także wypaczać rzeczywistość, ukazywać karykaturalny obraz wiary i Kościoła, przedstawiać fałszywą wizję dobra i zła, religii, a nawet ludzkości ${ }^{84}$.

Wobec dominacji cywilizacji obrazu w kulturze popularnej, gwałtownego rozwoju technik i urządzeń służących komunikacji społecznej oraz rozpowszechnianiu rozmaitych przekazów medialnych, niemal wszechobecności mediów i powszechnego korzystania $z$ technologii cyfrowych przez dzieci i młodzież, papieski postulat edukacji medialnej stanowił nie tylko aktualną odpowiedź na wyzwania i potrzeby nowych czasów, ale zarazem ukazywał konieczne kierunki współczesnego procesu wychowania, uwzględniającego nauczanie

\footnotetext{
82 Por. Konferencja Episkopatu Polski, Dyrektorium katechetyczne Kościoła katolickiego w Polsce, p. 48, www.katecheza.episkopat.pl/index.php/menu/dokumenty-na-temat-wychowania-i-katechezy/70-polskie-dyrektorium-katechetyczne (dostęp: 21.03.2016 r.).

${ }^{83}$ Zob. Jan Paweł II, Telewizja $w$ rodzinie..., dz. cyt., s. 196.

84 Zob. Jan Paweł II, Kształtowanie opinii publicznej, w: Orędzia papieskie..., dz. cyt., s. 141-145.
} 
oraz formację w czasach gwałtownych przemian kulturowych, obyczajowych i cywilizacyjnych.

\section{Nagradzany i krytykowany przez media}

Niezwykła osobowość Jana Pawła II oraz wyjątkowo dynamiczny sposób sprawowania papieskiej posługi, harmonijnie łączący urząd $z$ charyzmatem oraz aktywność $z$ kontemplacją, były nie tylko dostrzegane przez media, ale i nagradzane prestiżowymi wyróżnieniami. Już na początku pontyfikatu niemiecki dziennik Die Welt przyznał papieżowi tytuł Człowieka Roku, w 1994 r. uczynił to największy amerykański tygodnik Time ${ }^{85}$, a w 1995 r. - włoski miesięcznik Liberal $^{86}$ .W 2004 r. Jan Paweł II został uznany przez czytelników elitarnego brytyjskiego dziennika Financial Times za najbardziej wpływowego Europejczyka ostatniego ćwierćwiecza ${ }^{87}$. Papież był postrzegany jako jeden z najpotężniejszych ludzi swoich czasów. Obok prezydenta USA Ronalda Reagana oraz premier Wielkiej Brytanii Margaret Thatcher jest uznawany za głównego animatora upadku komunizmu w Europie Środkowo-Wschodniej ${ }^{88}$.

Niejednokrotnie jednak papież Jan Paweł II bywał przez media również ostro krytykowany, głównie za twarde, nieustępliwe i bezkompromisowe głoszenie nauki Kościoła przede wszystkim w dziedzinie etyki seksualnej i biomedycznej, a więc zdecydowane sprzeciwianie się związkom homoseksualnym, praktykom antykoncepcyjnym, aborcji, eutanazji, in vitro. Papież bywał także krytykowany jako rzekomy konserwatysta blokujący zniesienie celibatu ${ }^{89}$, odmawiający kobietom prawa do przyjmowania święceń kapłańskich. Media fałszowały wizerunek Jana Pawła II, oskarżając go pochopnie i niesłusznie o brak reakcji wobec ujawnienia skandalicznych

\footnotetext{
85 Zob. J. Poniewierski, Pontyfikat 1978-2005, dz. cyt., s. 33, 271.

86 Zob. tamże, s. 283.

87 Zob. tamże, s. 395.

88 Por. J. O’Sullivan, Prezydent. Papież. Premier. Oni zmienili świat, Warszawa 2007, s. 317-318, 323.

89 Zob. tamże, s. 319.
} 
grzechów w Kościele, pomijały zaś milczeniem papieskie wysiłki zmierzające do rozwiązania sytuacji kryzysowych ${ }^{90}$.

Komentatorzy pontyfikatu Jana Pawła II po jego śmierci formułowali pejoratywne, błyskotliwe (w ich mniemaniu) hasła mające syntetycznie podsumować posługę papieża-Polaka. The New York Times napisał, że Jan Paweł II „wykorzystywał narzędzia nowoczesności, by walczyć przeciw nowoczesnemu światu"91. Brytyjski dziennik lewicowy The Guardian stwierdził, że Jan Paweł II był „doktrynerskim, autorytarnym papieżem" ${ }^{92}$ oraz opublikował artykuł oskarżający go o spowodowanie śmierci milionów katolików i innych ludzi na całym świecie, zaś hołd wobec zmarłego papieża porównał do moskiewskich defilad przed mauzoleum Lenina ${ }^{93}$. Janowi Pawłowi II przypisywano średniowieczną wizję katolicyzmu, papieski absolutyzm, nieprzejednaną krytykę nowoczesności, demonizowanie XX wieku, a nawet niszczenie Kościoła ${ }^{94}$. Prymitywne, powierzchowne i nieprzyjazne oceny były konfrontowane z opiniami pogłębionymi, kompetentnymi i pozytywnymi, akcentującymi humanitaryzm, uczciwość i prawość Jana Pawła II. Takie przekonanie wyraził The Washington Post; angielski The Daily Telegraph podkreślił, że w czasach Jana Pawła II papiestwo nabrało wyjątkowego znaczenia politycznego i społecznego, zaś The Wall Street Journal zaakcentował zakorzenienie papieża-Polaka w ortodoksyjnej wierze i tradycji chrześcijańskiej ${ }^{95}$. Wszelkie głosy negatywne, odnoszące się do zmarłego papieża, zostały zagłuszone podczas jego pogrzebu wołaniem wiernych Santo subito!

Papież Jan Paweł II poprzez swoją bezpośredniość nadał nową jakość relacjom Kościoła z mediami. Był wzorem zachowania nowoczesnego człowieka wobec mediów: podkreślając ich przedmiotowy charakter i podmiotową wartość, ukazywał je jako narzędzia oraz

\footnotetext{
90 Zob. S. Dziwisz, U boku Świętego..., dz. cyt., s. 99-100.

91 Cyt. za: G. Weigel, Kres i początek. Papież Jan Paweł II - zwycięstwo wolności, ostatnie lata, dziedzictwo, Kraków 2012, s. 416.

92 Tamże.

93 Zob. tamże.

94 Zob. tamże, s. 417.

95 Zob. tamże.
} 
obszar ludzkiej aktywności i twórczości; postulował ich wykorzystywanie dla dobra człowieka, Kościoła i całej ludzkości; wzywał Kościół do ewangelizowania zarówno mediów, jak i poprzez media; apelował o realizację edukacji medialnej, uczącej korzystania i użytkowania nowoczesnych środków przekazu i komunikacji.

Bogactwo nauczania Jana Pawła II o mediach wciąż stanowi aktualny obszar badawczy oraz punkt odniesienia wobec nowych wyzwań i zjawisk występujących w gwałtownie zmieniającym się świecie mediów. Warto jednak zauważyć, że od czasów Piusa XII i jego opublikowanej w 1957 r. encykliki Miranda prorsus dotyczącej radia, telewizji i kinematografii żaden papież - nawet Jan Paweł II - nie opublikował nowej encykliki o mediach. Najobszerniejszy poświęcony im dokument Jana Pawła II - Szybki rozwój - ogłoszony w 2005 r. jest bowiem listem apostolskim. Zasadne wydaje się jednak postawienie pytania o sens encykliki o mediach, która już w chwili opublikowania może być w jakiejś mierze nieaktualna z powodu błyskawicznego rozwoju spowodowanego wprowadzeniem nowych urządzeń i technologii całkowicie zmieniających świat mediów i ich użytkowników.

\section{Streszczenie}

Przypomnienie okoliczności i fenomenu wyboru Polaka na Stolicę Piotrową. Statystyka wielkiego pontyfikatu. Przedstawienie Jana Pawła II jako bohatera, a zarazem odbiorcy mediów, a także jako ewangelizatora i twórcy mediów oraz realizatora edukacji medialnej, nagradzanego i krytykowanego przez media.

\section{Summary}

This article recalls the circumstances that brought about the election of Cardinal Karol Wojtyla a pope. The author focuses on the statistics of this great pontificate and tackles the phenomenon of John Paul II who was the maker and the recipient of his mass media success. As an evangelising pilgrim, John Paul II had soon exposed himself to as much veneration as criticism worldwide. 
Słowa kluczowe: papież Jan Paweł II, mass media, pontyfikat, bohater i odbiorca mediów, ewangelizator i twórca mediów, nagrody i krytyka

Key words: Pope John Paul II, the mass media, pontificate, veneration as criticism

\section{Bibliografia}

50 lat temu papież Jan XXIII otworzył obrady Soboru Watykańskiego II, http://dzieje.pl/aktualnosci/50-lat-temu-papiez-jan-xxiii-otworzyl-obrady-soboru-watykanskiego-ii (dostęp: 11.01.2016 r.).

Baczyński A., Jan Paweł II - blask osoby w telewizji, w: A. Baczyński, M. Drożdż, Nie lękajcie się. Jan Paweł II i media, Kraków 2011.

Dopierała K., Księga papieży, Poznań 1996.

Dziwisz S., Drążek C., Cierpienie w życiu i nauczaniu Jana Pawła II, w: Pozwólcie mi odejść. Siła w słabości Jana Pawła II, Częstochowa 2006.

Dziwisz S., Świadectwo w rozmowie $z$ Gian Franco Svidercoschim, Warszawa 2007.

Dziwisz S., U boku Świętego. Rozmowa z Gian Franco Svidercoschim, Kraków 2013.

Frossard A., „Nie lękajcie się!” Rozmowy z Janem Pawłem II, Watykan 1982.

Garbicz A., Lis M., Filmowe portrety pontyfikatu. Jan Paweł II w 100 odsłonach, Katowice 2007.

Jan Paweł II - Papież śpiewa, www.youtube.com/watch?v=9F5GYIt1hYE (dostęp: 01.03.2016 r.).

Jan Paweł II, Dar i Tajemnica. W pięćdziesiątą rocznicę moich święceń kapłańskich, Kraków 1996.

Jan Paweł II, Dobra Nowina w świecie mediów, w: Media i dziennikarstwo w nauczaniu Jana Pawła II, red. A. Lewek, Warszawa 2008.

Jan Paweł II, Dziennikarstwo jak kapłaństwo jest powołaniem, w: Media i dziennikarstwo w nauczaniu Jana Pawła II, red. A. Lewek, Warszawa 2008.

Jan Paweł II, Komunikacja społeczna pomostem pomiędzy wiarq a kultura, w: Orędzia papieskie na Światowe Dni Komunikacji Społecznej 1967-2002, red. M. Lis, Częstochowa 2002.

Jan Paweł II, Kształtowanie opinii publicznej, w: Orędzia papieskie na Światowe Dni Komunikacji Społecznej 1967-2002, red. M. Lis, Częstochowa 2002. 
Jan Paweł II, Misja dziennikarza wymaga kompetencji zawodowej i odpowiedzialności moralnej, w: Media i dziennikarstwo w nauczaniu Jana Pawła II, red. A. Lewek, Warszawa 2008.

Jan Paweł II, Pamięć i tożsamość. Rozmowy na przełomie tysiacleci, Kraków 2005.

Jan Paweł II, Redemptoris missio. Encyklika o stałej aktualności posłania misyjnego, w: Encykliki Ojca Świętego Jana Pawła II, Kraków 2009.

Jan Paweł II, Rola kaset magnetofonowych i magnetowidowych $w$ ksztaltowaniu kultury i sumienia, w: Orędzia papieskie na Światowe Dni Komunikacji Społecznej 1967-2002, red. M. Lis, Częstochowa 2002.

Jan Paweł II, Telewizja w rodzinie: kryteria właściwego wyboru programów, w: Orędzia papieskie na Światowe Dni Komunikacji Społecznej 1967-2002, red. M. Lis, Częstochowa 2002.

Jan Paweł II, Wskazania Kościoła w 100-lecie kinematografii, w: Media i dziennikarstwo w nauczaniu Jana Pawła II, red. A. Lewek, Warszawa 2008.

Jan Paweł II, Wstańcie, chodźmy!, Kraków 2004.

Jan Pawet II. Encyklopedia dialogu i ekumenizmu, red. E. Sakowicz, Radom 2006.

Karczewski S., Jan Paweł II. Encyklopedia pontyfikatu 1978-2005, Radom 2005.

Konferencja Episkopatu Polski, Dyrektorium katechetyczne Kościoła katolickiego w Polsce, p. 48, www.katecheza.episkopat.pl/index.php/menu/ dokumenty-na-temat-wychowania-i-katechezy/70-polskie-dyrektorium-katechetyczne (dostęp: 21.03.2016 r.).

Ku jakiej zmierzamy Europie? Wywiad udzielony Jasiowi Gawrońskiemu dnia 24 października 1993 r. w Rzymie, w: Jan Paweł II, Nauczanie społeczne Kościoła integralna częścia Jego misji. Wywiady, Rzym 1996.

Lecomte B., Pasterz, Kraków 2006.

Leksykon pielgrzymek Jana Pawła II, red. A. Jackowski, I. Sołjan, Kraków 2005.

Levinson P., Nowe nowe media, Kraków 2010.

Łęcicki G., Jan Pawet II. Miłośnik Krzyża i Zmartwychwstania, Warszawa 1998.

Łęcicki G., Jan Paweł II. Starałem się mówić za was. O papieskich pielgrzymkach do zniewolonej Ojczyzny 1979, 1983, 1987, Warszawa 2008.

Łęcicki G., Media audiowizualne w nauczaniu Jana Pawła II, Warszawa 2013. 
Łęcicki G., Nachylenie Boga. O młodzieńczej poezji Karola Wojtyły, Warszawa 2006.

Łęcicki G., Pierwsze polskie wizerunki filmowe Jana Pawła II, „Studia Theologica Varsaviensia" 2014, nr 1.

Media i dziennikarstwo w nauczaniu Jana Pawła II, red. A. Lewek, Warszawa 2008.

O’Sullivan J., Prezydent. Papież. Premier. Oni zmienili świat, Warszawa 2007.

Papież Jan Pawet II śpiewa "Góralu czy ci nie żal” z Japończykami, www. youtube.com/watch?v=KajTXhPUqCM (dostęp: 01.03.2016 r.).

Pieśń o Bogu ukrytym. Wiersze Karola Wojtyły śpiewa Marcin Styczeń, CD, Warszawa-Olkusz 2006.

Podpora R., Watykan i internet, www.e-mentor.edu.pl/artykul/index/numer/18/id/391 (dostęp: 13.03.2016 r.).

Podsiad A., Szafrańska A., Pierwsze dni pontyfikatu Jana Pawła II, Warszawa 1983.

Poniewierski J., Pontyfikat 1978-2005, Kraków 2005.

Prus B., Lalka, t. I, Warszawa 2003.

Przekroczyć próg nadziei. Jan Paweł II odpowiada na pytania Vittoria Messoriego, Lublin 1994.

Rekordy pontyfikatu papieża Jana Pawła II. O pontyfikacie Jana Pawła II, www.antoni.agmk.net/index.php?go=swieci_1/JP_II/rekordy (dostęp: 01.03.2016 r.).

Riccardi A., Jan Paweł II. Biografia, Częstochowa 2014.

Weigel G., Kres i początek. Papież Jan Paweł II - zwycięstwo wolności, ostatnie lata, dziedzictwo, Kraków 2012.

Weigel G., Świadek nadziei. Biografia papieża Jana Pawła II, Kraków 2000.

Grzegorz Łęcicki - ur. w 1958 r. w Warszawie; apologetyk, teolog kultury oraz mediów; prof. UKSW, dr hab., od 2013 r. kierownik katedry Teologii Środków Społecznego Przekazu w Instytucie Edukacji Medialnej i Dziennikarstwa na Wydziale Teologicznym Uniwersytetu Kardynała Stefana Wyszyńskiego w Warszawie; nauczyciel akademicki o bogatym doświadczeniu medialnym jako dziennikarz i publicysta prasowy oraz radiowy; w 2000 r. wyróżniony Medalem Mater Verbi przyznawanym przez Tygodnik Katolicki „Niedziela”; realizator autorskiego programu edukacji medialnej (2003-2010); od 2005 do 2012 r. wykładowca, a w latach 2007-2011 prorektor Warszawskiej Wyższej 
Szkoły Humanistycznej im. Bolesława Prusa; autor kilku monografii o życiu, posłudze i nauczaniu Jana Pawła II oraz innych publikacji; badacz mediów audiowizualnych, autor licznych artykułów naukowych dotyczących seriali telewizyjnych oraz filmów fabularnych. 